Article

\title{
Sulfonated Polyether Ether Ketone and Organosilica Layered Nanofiller for Sustainable Proton Exchange Membranes Fuel Cells (PEMFCs)
}

\author{
Ernestino Lufrano *, Cataldo Simari $\mathbb{C}^{\mathbb{C}}$, Apostolos Enotiadis ${ }^{\dagger}$ and Isabella Nicotera *(1)
}

Citation: Lufrano, E.; Simari, C.; Enotiadis, A.; Nicotera, I. Sulfonated Polyether Ether Ketone and Organosilica Layered Nanofiller for Sustainable Proton Exchange Membranes Fuel Cells (PEMFCs) Appl. Sci. 2022, 12, 963. https:// doi.org/10.3390/app12030963

Academic Editor: Guntae Kim

Received: 21 December 2021

Accepted: 17 January 2022

Published: 18 January 2022

Publisher's Note: MDPI stays neutral with regard to jurisdictional claims in published maps and institutional affiliations.

Copyright: (C) 2022 by the authors. Licensee MDPI, Basel, Switzerland. This article is an open access article distributed under the terms and conditions of the Creative Commons Attribution (CC BY) license (https:// creativecommons.org/licenses/by/ $4.0 /)$.
Department of Chemistry and Chemical Technologies, University of Calabria, 87036 Rende, Italy; cataldo.simari@unical.it (C.S.); aenotiadis@gmail.com (A.E.)

* Correspondence: ernestino.lufrano@unical.it (E.L.); isabella.nicotera@unical.it (I.N.)

+ Current address: QACS, The Challenge Test Lab-Laboratory Testing Solutions, Packaging Specialist, Antigonis 1 Metamorfosi, 14451 Athens, Greece.

\begin{abstract}
The ease and low environmental impact of its preparation, the reduced fuel crossover, and the low cost, make sulfonated polyether ether ketone (sPEEK) a potential candidate to replace the Nafion ionomer in proton exchange membrane fuel cells (PEMFCs). In this study, sPEEK was used as a polymer matrix for the preparation of nanocomposite electrolyte membranes by dispersing an organo-silica layered material properly functionalized by anchoring high phosphonated $\left(\mathrm{PO}_{3} \mathrm{H}\right)$ ionic groups (nominated PSLM). sPEEK-PSLM membranes were prepared by the solution intercalation method and the proton transport properties were investigated by NMR (diffusometry-PFG and relaxometry- $\mathrm{T}_{1}$ ) and EIS spectroscopies, whereas the mechanical properties of the membranes were studied by dynamic mechanical analysis (DMA). The presence of the organosilica nanoplatelets remarkably improved the mechanical strength, the water retention capacity at high temperatures, and the proton transport, in particular under harsh operative conditions (above $100{ }^{\circ} \mathrm{C}$ and $20-30 \%$ $\mathrm{RH})$, usually required in PEMFCs applications.
\end{abstract}

Keywords: proton exchange membrane fuel cells; sPEEK; organosilica layered material; nanocomposite membranes; solution intercalation; PFG-NMR; water retention; proton transport

\section{Introduction}

Among all of the electrochemical energy generators, proton exchange membrane fuel cells (PEMFCs) are one of the most promising technology for the clean, safe, and efficient generation of electric power [1]. Indeed, PEMFC has an energy to weight ratio ten times greater than lithium-ion batteries. This means that hydrogen powered vehicles have the potential to offer much greater range, while being lighter. In addition, while lithium batteries have a limited lifespan and need to be replaced [2], fuel cells do not degrade in the same way. They continue to produce energy as long as the fuel source is present, which can have significant environmental benefits over the normal working lifespan. The only exception is flow batteries, which have properties of both conventional batteries and fuel cells, but suffer from severe power and energy density limitations and typically require expensive and corrosive or toxic fluids to operate [3]. However, one of the challenges for the large-scale development of PEMFC devices is to increase the operating temperature of the cell from the current $70-90{ }^{\circ} \mathrm{C}$ to about $120{ }^{\circ} \mathrm{C}$ (DOE target [4]). This would allow for better kinetics of reactions at the electrodes, easier water management, and would thus reduce the complexity of the system and consequently reduce costs [5]. Surely, the crucial component of the cell, which strongly influences performance and cost, is the electrolytic membrane. The state of the art is based on a perfluorosulfonic acid ionomer, the most famous of which is Nafion ${ }^{\circledR}$, produced by Dupont. Nafion has a hydrophobic Teflonlike backbone, which confers elevated chemical, thermal, and mechanical stability to the 
polymer, while the ion transport properties are guaranteed by the presence of hydrophilic long side sulfonic groups. In fact, the phase separation between these two hydrophobic and hydrophilic domains leads to the formation of channels for ion transportation [6-8]. However, disadvantages like the high cost (about $800 \$ / \mathrm{m}^{2}$ ), the high environmental impact particularly related to the synthesis of a perfluorinated polymer, the low ability to retain water over the $100{ }^{\circ} \mathrm{C}$ (required for the high temperature PEMFCs) [6], and the instability in a low hydration environment [9], must be considered. In this field, research focuses on new polymer electrolytes membranes with a good proton conductivity ability to maintain hydration at temperatures above $100{ }^{\circ} \mathrm{C}[10,11]$. The starting point is to develop new sulfonated polymers that are chemically and thermally stable, cheaper and at low impact, and with proton conductivity and cell performance comparable to Nafion, which can act as a suitable polymer matrix to design and synthesize innovative nanocomposite membranes [12,13]. Good results were achieved on the sulfonated derivatives of poly (arylene ethers) [14], polysulfone [15], polyethersulfone [16], poly (arylene sulfide sulfone nitrile) [17], and poly (ether ether ketone) [18]. However, in most of the cases, the excessive swelling, which reduces the mechanical properties, and the relative low conductivity actually hampered the use of these membranes in PEMFCs applications [19]. Therefore, to overcome these drawbacks, the incorporation of an appropriate nanoadditive inside the polymer matrix is the main route to improve both proton conductivity and membrane strength [20-23].

Generally, hygroscopic inorganic fillers, such as $\mathrm{SiO}_{2}, \mathrm{TiO}_{2}, \mathrm{ZrO}_{2}$, phosphotungic acid, or zeolite nanoparticles, would increase the water retention capacity and accordingly the proton conduction of the final composite membrane [24-26]. In the last few years, 2Dnanomaterials, such as nanoclays, layered double hydroxides (LDH), and graphene oxide, have been successfully used by Nicotera and coworkers [16,27]. They are characterized by hydrophilic nano-lamellae with a large surface area and high aspect ratio, which can be easily functionalized and exfoliated in a polymer matrix. The resulting completely exfoliated nanocomposites show enhanced mechanical resistance, reduced fuel crossover, and outstanding ion conductivities above $90-100{ }^{\circ} \mathrm{C}[28,29]$. In this study, the sulfonated polyether ether ketone (sPEEK) derivative at a specific degree of sulfonation was chosen as the polymer matrix due to its low cost, high availability, low environmental impact, and outstanding thermo-mechanical strength. SPEEK is a copolymer consisting of non-sulfonated PEEK structural units that are hydrophobic, and sulfonated PEEK units that are hydrophilic. This structure allows for a phase micro-separation similar to that which occurs in Nafion, with hydrophobic domains that give mechanical strength to the membrane, and hydrophilic domains that absorb significant amounts of water and are therefore responsible for proton conduction [30]. The efficient and low-cost nanocomposite electrolyte membranes have been obtained by the dispersion of an organo-silica layered material (SLM) [27]. SLMs are 2D nanostructures of a very simple, inexpensive, one-pot synthesis with a high surface area, which can be easily functionalized with appropriate functional groups. Preliminary studies on SLM decorated with sulfonic groups demonstrated good chemical affinity and facile exfoliation and dispersion in polymer matrices [31,32], producing nanocomposite electrolyte membranes with an improved thermal stability and proton conductivity.

In the present work, SLM was synthesized starting from a mono-functional silica precursor by the condensation mechanism, in order to provide phosphonate functional groups. The final nanomaterial, called PSLM, has a layered structure and the surface contains a high number of $\mathrm{PO}_{3}^{-}$groups. sPEEK-PSLM nanocomposite membranes with different filler loadings were prepared by a solution intercalation method. All the samples, pristine and nanocomposite membranes, were characterized in terms of proton transport properties, mechanical behavior (by dynamic mechanical analysis (DMA)) and dimensional stability. In particular, NMR spectroscopy was crucial to measure the water self-diffusion coefficients (pulse field gradient NMR method) and the relaxation times $\left(\mathrm{T}_{1}\right)$, while proton conductivities were evaluated by electrochemical impedance spectroscopy (EIS). 


\section{Materials and Methods}

\subsection{Materials and Chemicals}

Commercial polyether ether ketone (PEEK, Victrex 450PF) was supplied by ICI (London, UK) and was dried in a vacuum oven overnight at $100{ }^{\circ} \mathrm{C}$ for $24 \mathrm{~h}$ prior to use. Sulfuric acid (95-98 wt.\%, Sigma-Aldrich, Milan, Italy), N, N-Dimethylacetamide (DMAc, SigmaAdrich, Milan, Italy), and $\mathrm{NaOH}$ (0.1 M, volumetric standard, Sigma-Aldrich, Milan, Italy) were all purchased by Aldrich and were used as received.

\subsection{Sulfonation of Polyether Ether Ketone}

The sulfonation of PEEK was made according to the methodology provided by Banerjee et al. [33]. Concisely, the dried polymer was dissolved in concentrated $\mathrm{H}_{2} \mathrm{SO}_{4}$ at room temperature and was stirred in order to get a homogeneous solution. Subsequently, the temperature was increased to $40{ }^{\circ} \mathrm{C}$ and was held at a specific reaction time to obtain sPEEK with a specific degree of sulfonation (in this work we chose a reaction time of $5 \mathrm{~h}$ ) [32]. To quench the solution, ice-cold distilled water was slowly added and a precipitate of sPEEK was formed. The resulting polymer flakes were recovered by filtration, vigorously washed with deionized water (until pH 6-7), and then heated at $60^{\circ} \mathrm{C}$ in an oven until dryness (for $24 \mathrm{~h})$.

\subsection{Synthesis of Organo-Silica Layered Materials}

The phosphonate organo-silica layered material (PSLM) was synthesized as follows: an appropriate amount of aqueous solution of silane 3-(trihydroxysilyl) propyl methyl phosphonate, monosodium salt $\left[(\mathrm{OH})_{3} \mathrm{Si}\left(\mathrm{CH}_{2}\right)_{3} \mathrm{OP}(\mathrm{O})\left(\mathrm{CH}_{3}\right) \mathrm{O}-\mathrm{Na}^{+}\right](50 \% \mathrm{w} / \mathrm{w}$, Gelest $)$ was put in an oven (at $80{ }^{\circ} \mathrm{C}$ for 5 days) until a cleaved and transparent xerogel was obtained [27,31]. Subsequently, distilled water (DI) was added to the xerogel, resulting in a milky suspension. Finally, the fine white powder was collected after successive washings (centrifugation parameters, $9000 \mathrm{rpm}$ for $5 \mathrm{~min}$ ) with DI (five times) and acetone (two times) and was dried at ambient conditions.

\subsection{Membranes Preparation}

Sulfonated polyether ether ketone was dissolved in DMAc (10\% wt. solution) at room temperature to get a clear and homogeneous solution. The membrane was obtained by casting the solution on a petri dish and was dried in an oven at $60{ }^{\circ} \mathrm{C}$ until complete evaporation of the solvent. To prepare exfoliated nanocomposite membranes, PSLM powder was initially dispersed in DMAc by alternating vigorous mechanical stirring with ultrasonication. This dispersion was then added dropwise to the polymer solution with continuous stirring at $60{ }^{\circ} \mathrm{C}$ to ensure complete mixing. The loading of PSLM particles added to the membrane was from 1 to $5 \%$ by weight with respect to the polymer. The casting of this dispersion on a Petri dish and subsequent heating in oven at $60{ }^{\circ} \mathrm{C}$ till dryness allowed for the preparation of the nanocomposite polymeric films. Finally, both pristine and composite membranes were converted into the acid form by soaking them in $0.5 \mathrm{M} \mathrm{H}_{2} \mathrm{SO}_{4}$ solution, followed by washing several times with boiling deionized water to remove any residual acid [27]. The dry thickness of the prepared membranes was circa $50 \pm 5 \mu \mathrm{m}$. Figure 1 shows the pictures of the polymer electrolyte membranes prepared in this study. Both pristine sPEEK and PSLM-based membranes are transparent yellowish, and appear homogeneous and free of big aggregates. 

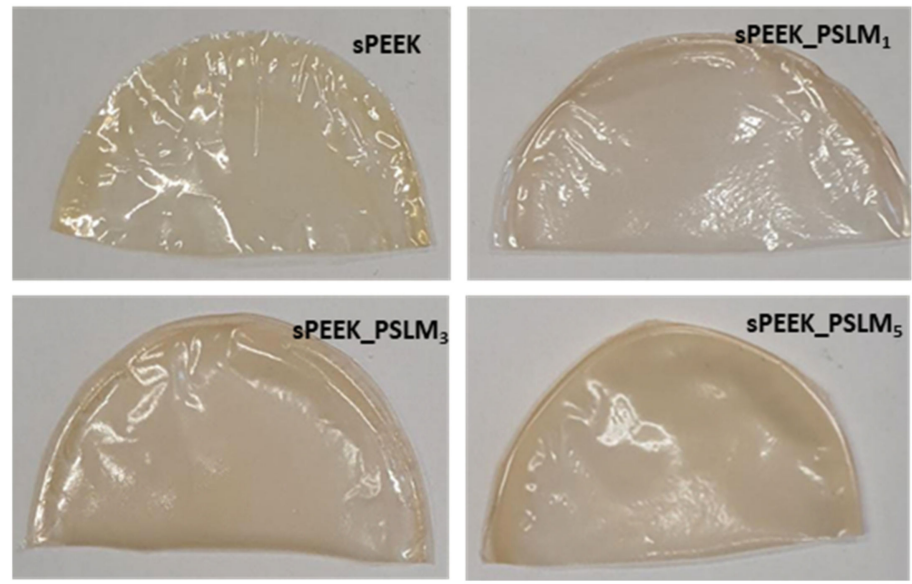

Figure 1. Pictures of pristine sPEEK and sPEEK_PSLM composites (at 1, 3, and 5\% of filler loading) membranes.

\subsection{Ion Exchange Capacity (IEC) and Water Uptake}

The ion exchange capacity (IEC) of the membranes was estimated using the standard titration method [34]. Samples in acid form were immersed in a $2 \mathrm{M} \mathrm{NaCl}$ solution for $24 \mathrm{~h}$ at room temperature to completely release $\mathrm{H}^{+}$via exchanging with $\mathrm{Na}^{+}$. The amount of released $\mathrm{H}^{+}$was titrated with a standard $\mathrm{NaOH}$ solution $(0.1 \mathrm{M})$, using phenolphthalein as an indicator. The IEC values (meq g ${ }^{-1}$ ) were calculated according to Equation (1) and reported as an average of at least three independent measurements:

$$
I E C=\frac{C_{(\mathrm{NaOH})} V_{(\mathrm{NaOH})}}{W_{d r y}} ; \text { meq g- }{ }^{1}
$$

where $C_{(\mathrm{NaOH})}$ is the concentration and $V_{(\mathrm{NaOH})}$ is the volume of $\mathrm{NaOH}$ solution consumed during titration.

From the IEC value, the sulfonation degree (DS\%) of the polymer was determined by Equation (2):

$$
D S[\%]=\frac{M_{(p)} \times I E C}{1000-\left(I E C-M_{(f)}\right)} \times 100 ; \%
$$

where $M(p)$ is the molecular weight of the PEEK repeat unit without the functional group, and $M(f)$ is the molecular weight of the sulfonic group $\left(-\mathrm{SO}_{3} \mathrm{H}\right)$. From the difference between the wet and dry mass of each membrane, the water uptake (w.u.) was measured. In detail, a rectangular shaped sample was directly cut from the membrane and dried in a conventional oven @ $120^{\circ} \mathrm{C}$ for $18 \mathrm{~h}$ to obtain the dry mass $\left(m_{d r y}\right)$. The sample was then swelled by immersing it in distilled water for $24 \mathrm{~h}$ at $20^{\circ} \mathrm{C}$ and at higher temperatures, in particular from 30 to $80^{\circ} \mathrm{C}$ each $10^{\circ} \mathrm{C}$, for $2 \mathrm{~h}$. After removing the sample from the distilled water, the surface was rapidly wiped with blotting paper to eliminate water droplets and was quickly weighted $\left(m_{w e t}\right)$. Accordingly, the water uptake was then calculated by Equation (3):

$$
w . u .=\frac{m_{w e t}-m_{d r y}}{m_{d r y}} \times 100 ; \%
$$

Therefore, the $\lambda$ value, i.e., the number of water molecules per $-\mathrm{SO}_{3} \mathrm{H}$ group, was calculated by Equation (4):

$$
\lambda=\frac{w \cdot u .}{\operatorname{IEC} \times M_{w}}
$$

where $M w$ is the molecular weight of water $\left(18.01 \mathrm{~g} \mathrm{~mol}^{-1}\right)$. 


\subsection{NMR (PFG and Relaxometry) Spectroscopy}

NMR measurements were performed using a Bruker NMR spectrometer AVANCE 300 Wide Bore working at $300 \mathrm{MHz}$ on ${ }^{1} \mathrm{H}$ and equipped with a Diff30 Z-diffusion $30 \mathrm{G} / \mathrm{cm} / \mathrm{A}$ multinuclear probe with substitutable RF inserts. Water self-diffusion coefficient (D) measurements were performed using the pulsed field gradient stimulated-echo (PFG-STE) method [35]. This sequence is opportune when the transverse relaxation time $\left(\mathrm{T}_{2}\right)$ is very low and is considerably shorter than the longitudinal relaxation time $\left(\mathrm{T}_{1}\right)$, and foresees three $90^{\circ}$ RF pulses $\left(\pi / 2-\tau_{1}-\pi / 2-\tau_{m}-\pi / 2\right)$ with two gradient pulses applied after the first and the third RF pulses, respectively. The echo is found at time of $\tau=2 \tau_{1}+\tau_{\mathrm{m}}$. The FT echo decays were analyzed by means of the relevant Stejskal-Tanner expression using Equation (5):

$$
I=I_{0} e^{-\beta D}
$$

with $I$ and $I_{0}$ representing the intensity/area of a selected resonance peak with and without gradients, respectively; $D$ being the self-diffusion coefficient; and $\beta$ being the field gradient parameter. This latter is defined by Equation (6):

$$
\beta=\left[(\gamma g \delta)^{2}\left(\Delta-\frac{\delta}{3}\right)\right]
$$

where $g, \delta$, and $\Delta$ are the amplitude, duration, and time delay of the gradient field, respectively. For the measurements, $\delta$ and $\Delta$ were kept at 0.8 and $8 \mathrm{~ms}$, respectively, while $g$ ranged between 50 up to $800 \mathrm{G} \mathrm{cm}^{-1}$. For the self-diffusion measurements, an uncertainty of $\sim 3 \%$ was calculated.

The spin-lattice relaxation times $\left(\mathrm{T}_{1}\right)$ was measured by the inversion recovery sequence $(\pi-\tau-\pi / 2)$.

The detailed experimental procedure to prepare the NMR sample is described elsewhere [31]. In short, before the NMR measurements, the membranes were dried in an oven, and were weighed and then immersed in distilled water at room temperature. After being removed from the water, they were quickly blotted dry with tissue paper (to eliminate most of the free surface liquid). Then, the water uptake was measured and the membranes were loaded into a $5 \mathrm{~mm}$ NMR Pyrex tube and closed with a normal cap.

Both $\mathrm{D}$ and $\mathrm{T}_{1}$ were investigated in the range $20-130{ }^{\circ} \mathrm{C}$, with steps of $20^{\circ} \mathrm{C}$ and 15 min of equilibration time for each temperature.

\subsection{Electrochemical Impedance Spectroscopy (EIS)}

Electrochemical impedance spectroscopy (EIS), with an in-plane cell configuration, was used to measure the proton conductivities of the prepared PEMs. For the in-plane measurements, rectangular shape samples were cut from the films and placed in a commercial four-electrode cell (BT-112, Scribner Associates Inc.) fitted between the anode and cathode flow field of a fuel cell test hardware (850C, Scribner Associates Inc.). Impedance response of the cell was recorded at $\mathrm{OCV}$ with an oscillating potential of about $10 \mathrm{mV}$ in the frequency range $1 \mathrm{~Hz}-1 \mathrm{MHz}$ by using a PGSTAT 30 potentiostat/galvanostat/FRA. The data were analyzed using Metrohm Autolab NOVA software and the electrolyte resistance was extracted as the intercept of the high frequency signal in the Nyquist plot. A humidification system (Fuel Cells Technologies, Inc., Albuquerque, NM, USA) directly connected to the cell allowed for investigating the proton conductivity under variable $\mathrm{T}$ and $\mathrm{RH}$.

\subsection{Dynamic Mechanical Analysis (DMA)}

Dynamic mechanical analysis (DMA) on the sPEEK-based membranes was performed on a Metravib DMA/ 25 analyzer equipped with a shear jaw for film clamping. Temperature tests were carried out by subjecting a rectangular shape sample ( $35 \mathrm{~mm} \times 10 \mathrm{~mm}$ ) to dynamic stress with an amplitude of $10^{-4}$ at $1 \mathrm{~Hz}$ frequency, from $25^{\circ} \mathrm{C}$ to $300^{\circ} \mathrm{C}$, with a heating rate of $2{ }^{\circ} \mathrm{C} / \mathrm{min}$. A periodic sinusoidal displacement was applied to the sample, 
and the resultant force was measured. The damping factor, $\tan \delta$, is defined as the ratio of loss $\left(E^{\prime \prime}\right)$ to storage $\left(E^{\prime}\right)$ modulus, with $T_{g}$ as the peak of $\tan \delta$ versus temperature.

\section{Results and Discussion}

\subsection{Mechanical Properties}

Dynamic mechanical analysis (DMA) was used to study the mechanical strength of the PEMs upon adding the PSLM nanoparticles. Figure $2 \mathrm{a}, \mathrm{b}$ shows the temperature evolution of the storage modulus and the dumping factor $(\tan \delta)$, respectively, for the sPEEK-based membranes. Commercial Nafion 212 membrane was also measured and the data are reported in the graphs for comparison. We can observe how the addition of PSLM platelets in the polymer matrix resulted in a marked increase of the storage modulus and in an appreciable extension of the thermal resistance. For instance, the storage modulus of the sPEEK-based membranes remained quite constant, at least up to $200{ }^{\circ} \mathrm{C}$, and with values of one order of magnitude higher than Nafion 212 (Figure 2a). The addition of the silica nanofiller improved the robustness and, for example, the sPEEK-PSLM 3 sample displayed a storage modulus of about $280 \mathrm{MPa}$, which is four-fold higher than pristine sPEEK. Furthermore, the introduction of the silica-based nanoplatelets also has a beneficial effect on the thermal properties of the membrane. This can be clearly seen from the temperature evolution of $\tan \delta$, illustrated in Figure $2 \mathrm{~b}$. For each membrane, the dumping factor plot exhibits a single peak, which can be assigned to the $\alpha$ transition $\left(\mathrm{T}_{\mathrm{g}}\right)$ of the ionic clusters of the polymer. While Nafion [36] exhibits a $\mathrm{T}_{\mathrm{g}}$ of ca. $120^{\circ} \mathrm{C}$, the $\alpha$-transition for SPEEK is shifted at remarkably higher temperatures, i.e., above $200^{\circ} \mathrm{C}$. This indicates this polyaromatic polymer can definitively withstand higher operating temperatures with respect to the Nafion benchmark. For the SPEEK-based nanocomposites, the increasing filler content moves the peak further toward a higher temperature, reaching an impressive value of $245^{\circ} \mathrm{C}$ at $3 \mathrm{wt} \%$ of filler loading. De facto, the nanocomposite membrane conjugate had outstanding mechanical strength with impressive thermal stability, and can be potentially applied in PEMFCs able to effectively operate under harsh conditions, which are high temperature and severe mechanical solicitations.

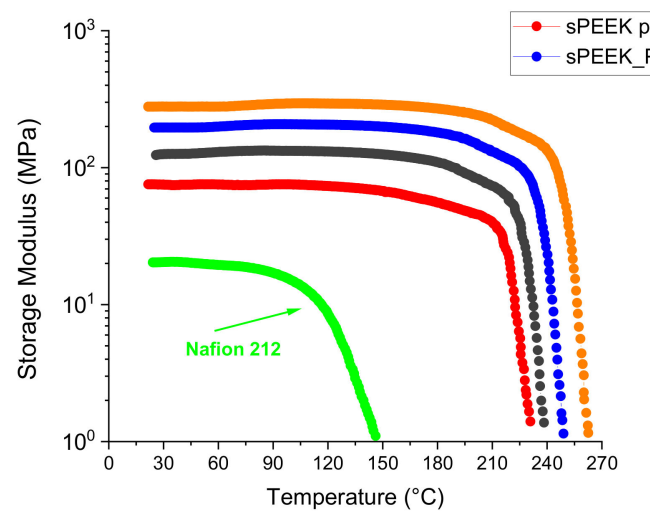

(a)

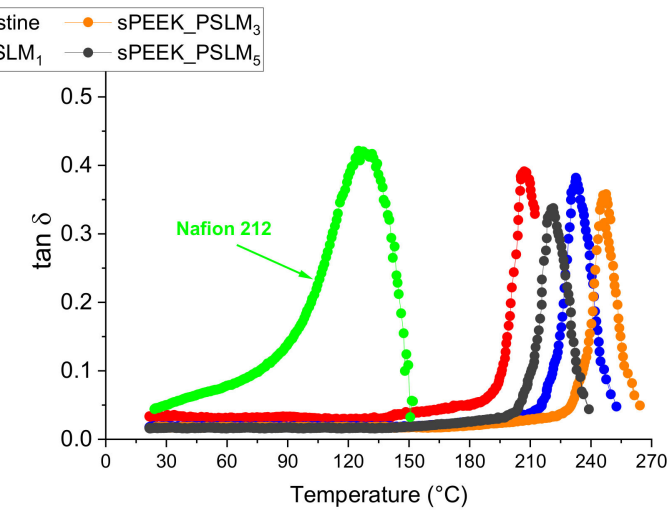

(b)

Figure 2. (a) Storage modulus ( $\left.E^{\prime}\right)$ and (b) $\tan \delta$ of the sPEEK-based membranes as a function of temperature.

\subsection{IEC and Water Uptake}

The ion exchange capacity (IEC) and the water uptake of the sPEEK-based composite membranes have been measured and are shown in Figure 3, as well as a function of the filler amount. The membrane's IEC grows by the addition of the filler because it enhances the number of organo-phosphoric functionalities that are grafted onto the PSLM lamellae surface. The highest IEC value, $1.98 \mathrm{meq} \mathrm{g}^{-1}$, is achieved with $3 \mathrm{wt} \%$ of filler loading. By further increasing the loadings ( $5 \mathrm{wt} \%$ ), not only did IEC not improve, but a reduction was observed. This effect can be rationalized by considering (i) the formation 
of agglomerations between the nanoparticles, with the formation of clusters, and (ii) the only partial exfoliation of the siliceous layered nano-particles in the polymer. In both cases, a decrease of the number of hydrophilic sites available for proton exchange is achieved. In parallel, such features clearly affect the water absorption capacity of the electrolyte membranes [37]. The water uptake varies between $40 \mathrm{wt} \%$ of the pristine sPEEK and the $50 \mathrm{wt} \%$ of the sPEEK-PSLM 3 . Therefore, the introduction of PSLM platelets increases the hydrophilicity of the PEMs, however no excessive membrane swelling is produced by the filler addition.

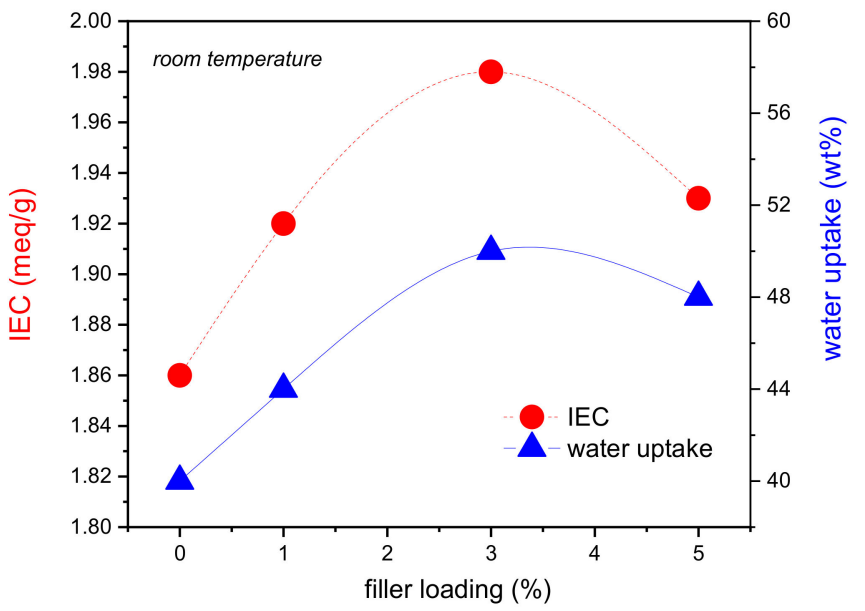

Figure 3. Ion exchange capacity and water uptakes of sPEEK/PSLM composite membranes as a function of the filler loadings.

Further insights concerning the membrane swelling behavior can be achieved under variable temperatures, as reported in Figure 4, where both water uptake and $\lambda$ (i.e., number of water molecules per mole of acid group have been evaluated in the temperature range 20-80 ${ }^{\circ} \mathrm{C}$. The swelling clearly increases by heating, however, the composite at $3 \%$ filler loading shows a lower swelling just at higher temperatures, with respect to both pristine SPEEK and the composites at 1 and $5 \%$ of filler.
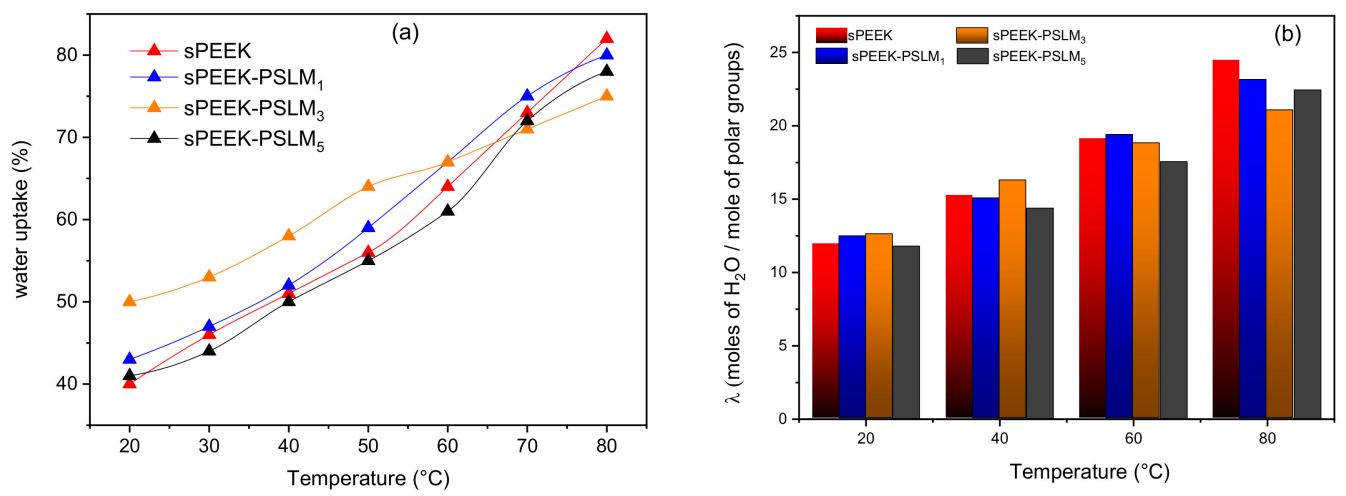

Figure 4. Temperature evolution of (a) the water uptake and (b) $\lambda$ for pristine sPEEK and sPEEKPSLM composite membranes.

The $\lambda$ behavior (Figure $4 \mathrm{~b}$ ) gives information on the membrane's microstructure. We observed that at $20^{\circ} \mathrm{C}, \lambda$ is almost invariable (about 12) among the various samples, meaning that the presence of PSLM nanoparticles within the polymer matrix does not actually change the microstructure and size of the ionic clusters, but it does affect the distribution of water molecules within these hydrophilic regions to some extent. In particular, the $\mathrm{SPEEK}-\mathrm{PLSM}_{3}$ sample shows a slightly different trend from the other membranes, i.e., above $50{ }^{\circ} \mathrm{C}$, there is no linear increase in water uptake as expected. This means that for this membrane, the structural organization of the exfoliated filler does not allow for an 
excessive swelling of the hydrophilic pores, but provides the right distribution of water molecules between the acidic sites of the polymer and the nanoparticles.

\subsection{PFG-NMR Investigation}

The proton transport properties and the molecular dynamics of water confined inside the hydrophilic clusters of the PEMs have been investigated by ${ }^{1} \mathrm{H}-\mathrm{NMR}$ spectroscopy, and, in particular, the direct measurements of the water self-diffusion coefficients (D) and the longitudinal relaxation times $\left(\mathrm{T}_{1}\right)$ [38]. The water self-diffusion coefficients (D) measured on completely swollen PEMs in the temperature range of $20-130{ }^{\circ} \mathrm{C}$ are shown in Figure 5. In the $20-60^{\circ} \mathrm{C}$ temperature range, we can observe a similar behavior of $\mathrm{D}$ among the samples, where the few different values are due to the initial water contents in the membranes. However, above $60{ }^{\circ} \mathrm{C}$, the diffusivity trend begins to diverge abruptly. In fact, pristine sPEEK shows a brusque decrease of $\mathrm{D}$ and at $130{ }^{\circ} \mathrm{C}$ the $\mathrm{D}$ value is about one order of magnitude lower than the initial ones at room temperature. On the other hand, the nanocomposite PEMs show only a slight decrease in diffusivity only above $100{ }^{\circ} \mathrm{C}$ or even invariability for the sample at $3 \mathrm{wt} \%$ of filler loading. It is worth pointing out that during these measurements, the relative humidity on the NMR tube is not controlled and no hydration system is provided, but the tube is simply sealed. Therefore, during heating, the water confined in the membranes can evaporate above $90-100{ }^{\circ} \mathrm{C}$. The data clearly show that the pristine sPEEK membrane cannot retain water above $60-80{ }^{\circ} \mathrm{C}$, while the PSLM nanomaterial is able to maintain a certain degree of hydration at a high temperature. Among the nanocomposite membranes, the sPEEK_LDH $\mathrm{L}_{3}$ sample displayed the best behavior, as the water diffusivity continues to grow slightly up to $130{ }^{\circ} \mathrm{C}$. This result indicates that the dispersion of a correct amount of PSLM creates the right condition for the electrolyte membrane to be able to work at high temperatures and low humidity, addressing one of the crucial requirements for PEMFCs.

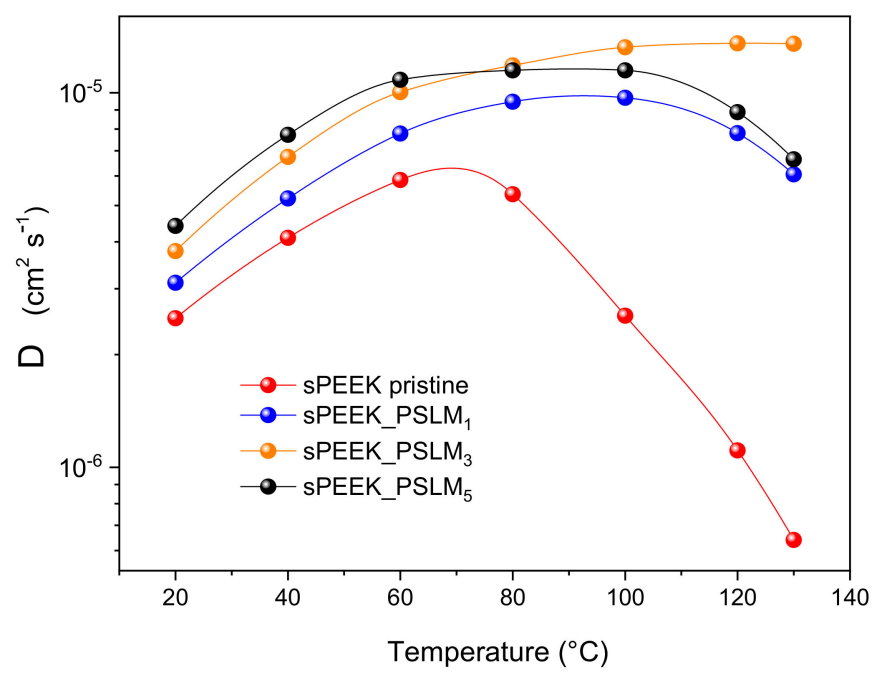

Figure 5. Self-diffusion coefficients (D) as a function of the temperature (from $20^{\circ} \mathrm{C}$ to $130{ }^{\circ} \mathrm{C}$ ) of the water confined in sPEEK-based membranes.

The analysis of spin-lattice relaxation times $\left(\mathrm{T}_{1}\right)$ was able to shed more light on aspects of water distribution within the ionic clusters of PEMs. Compared to $\mathrm{D}, \mathrm{T}_{1}$ refers to more localized motions, including both translation and rotation on a time scale comparable to the reciprocal of the NMR angular frequency (few nanoseconds). Generally lower $\mathrm{T}_{1}$ values suggest stronger electrostatic interactions, which inhibit the molecular rotational and translational motion. Figure 6 reports the temperature behavior of $\mathrm{T}_{1}$ in the range $20-130{ }^{\circ} \mathrm{C}$. We can observe a significant difference between the trend in the filler-free sample and the nanocomposite membranes. In fact, while in the three composite PEMs, $\mathrm{T}_{1}$ slightly increases during the heating with a typical expected temperature behavior [39], where the pristine 
sPEEK sample shows higher $\mathrm{T}_{1}$ values at the beginning, which then fall rapidly and largely above $60{ }^{\circ} \mathrm{C}$, meaning that a fundamental change at the molecular level is taking place in the hydrophilic clusters of the membrane. Actually, the water molecules in sPEEK pristine, having lower interactions, are more susceptible to evaporation, therefore, above $60{ }^{\circ} \mathrm{C}$, the only water left in the membrane is that of the first hydration spheres, and therefore is strongly bound to the sulfonic groups of the polymer. Such water molecules suffer from much stronger electrostatic interactions, so that their rotational and/or translational motions are severely restricted, and $\mathrm{T}_{1}$ goes down. In the composite PEMs, on the other hand, there are no significant changes in $\mathrm{T}_{1}$, so this indicates that there are no substantial alterations at the molecular level: the water molecules are distributed between the various hydrophilic acid sites of the polymer and the filler, with interactions that evaporation is slowed down considerably even at a high $\mathrm{T}$. Slight flexing of $\mathrm{T}_{1}$ is observed at $120{ }^{\circ} \mathrm{C}$ for samples with 1 and 5\% filler, while it is absent in the $3 \%$ sample.

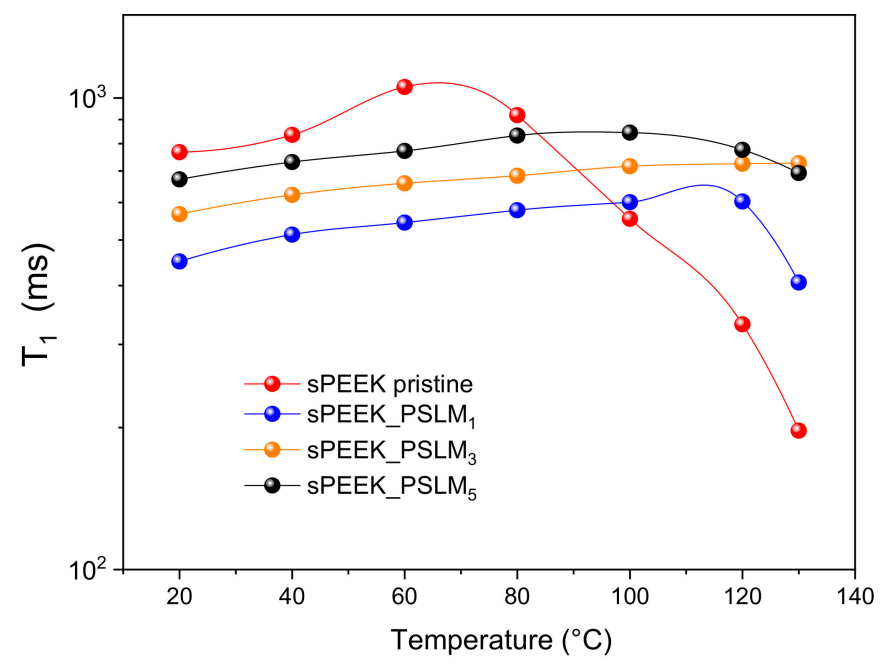

Figure 6. Spin-lattice relaxation times $\left(\mathrm{T}_{1}\right)$ as a function of the temperature (from $20^{\circ} \mathrm{C}$ to $130{ }^{\circ} \mathrm{C}$ ) of the water confined in sPEEK-based membranes.

\subsection{Proton Conductivities ( $\sigma$ ) and Hydrolytic Stability}

The proton conductivity of the sPEEK-based electrolyte membranes has been measured at $90^{\circ} \mathrm{C}$ and at different humidity conditions, as shown in Figure 7. Nafion 212 commercial membrane was used as the benchmark and it is also reported in the graph for comparison. As expected, the conductivity of pristine sPEEK is lower than that of Nafion 212. Indeed, the ion conductive channels of SPEEK are narrower and less interconnected compared to the Nafion ones as a consequence of the lower microphase separation between the hydrophilic and hydrophobic domains. This obviously has a detrimental effect on its proton transport properties. However, the nanodispersion of a filler such as this PSLM material allows for a significant improvement of $\sigma$ to be obtained under these operating conditions. In particular, the composite at $3 \mathrm{wt} \%$ filler loading achieves values not far from the benchmark. In addition, under low-hydration conditions ( $\mathrm{RH}=20-30 \%)$, an important prerequisite for the development of PEMFCs operating at temperatures above $10{ }^{\circ} \mathrm{C}$ and low humidity [40], the conductivity of the sPEEK-PSLM 3 membrane is very close to that of Nafion 212. 

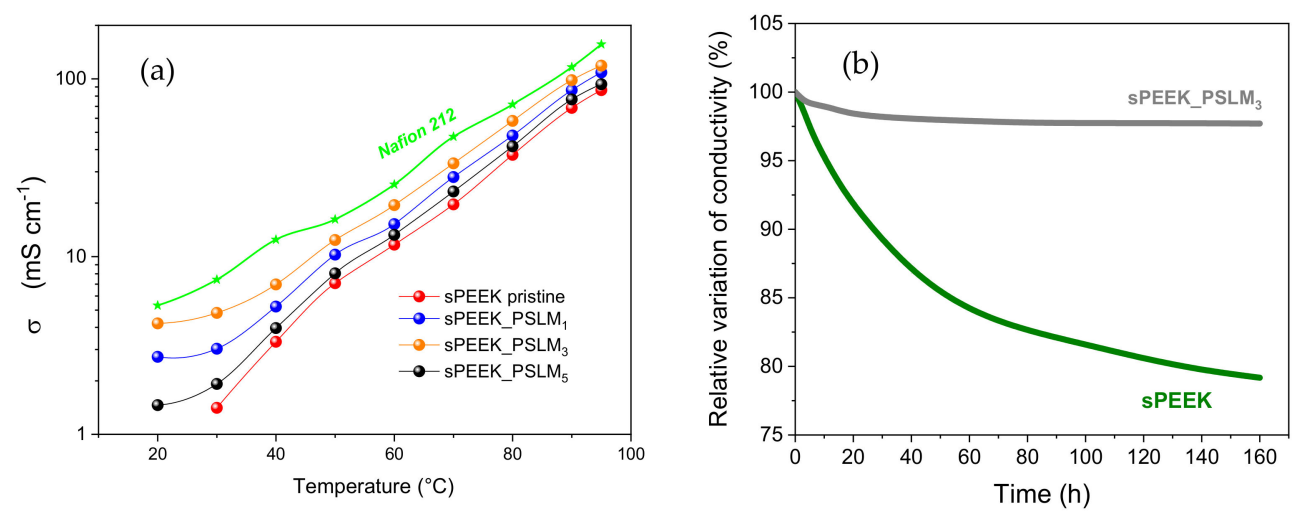

Figure 7. (a) Proton conductivity of sPEEK membranes and Nafion 212 at $90{ }^{\circ} \mathrm{C}$ as a function of RH. (b) Hydrolytic stability for sPEEK and sPEEK_PSLM 3 membranes at $90{ }^{\circ} \mathrm{C}$ and $95 \% \mathrm{RH}$ during $160 \mathrm{~h}$.

These results, together with the NMR outcomes seen above, prove that the dispersion of PSLM nanomaterials inside the sPEEK matrix creates an appropriate network that promotes effective proton transport by the more efficient Grotthuss-type mechanism through the formation of highly connected proton paths.

Finally, the long-term chemical stability of the sPEEK membranes was also evaluated. In this regard, the membranes were kept at $90{ }^{\circ} \mathrm{C}$ and $95 \% \mathrm{RH}$, and the decrease in proton conductivity was assumed as an indicator of membrane degradation. Figure $7 \mathrm{~b}$ illustrates the relative variation of $\sigma$ as a function of the treatment time (over $160 \mathrm{~h}$ ) for two representative membranes; i.e., pristine sPEEK and sPEEK_PSLM ${ }_{3}$. While pristine sPEEK undergoes a severe hydrolytic degradation (over $20 \%$ of conductivity loss after $160 \mathrm{~h}$ ), the variation for the nanocomposite membranes was almost negligible, i.e., $\sim 2.3 \%$ after $160 \mathrm{~h}$. Accordingly, the introduction of the organosilica platelets in the sPEEK matrix produced a remarkable increase in the chemical resistance of the PEM. We can hypothesize that the aqueous environment progressively decomposes the $-\mathrm{SO}_{3} \mathrm{H}$ groups, but the strong electrostatic interaction of these groups with the PSLM platelets prevents the polymer backbone from degradation.

\section{Conclusions}

sPEEK-PSLM nanocomposite membranes have been synthetized and investigated in terms of their mechanical properties and proton transport performance. Sulfonation of polyether ether ketone (sPEEK) was achieved by using a specific reaction time (i.e., $5 \mathrm{~h}$ ), whereas the synthesis of phosphonated silica layered materials (denoted as PSLM) was synthesized by the simple SOL-GEL approach. PEMs at three different filler loadings (1, 3, and $5 \mathrm{wt} \%$ with respect to the polymer) were prepared by a simple solution intercalation procedure. The introduction of PSLM materials produced significant strengthening of the mechanical resistance, improvement of the water retention capacity, and a favorable effect on the transport properties on the resulting nanocomposite membranes, as demonstrated by NMR and EIS investigations. The sample sPEEK-PSLM ${ }_{3}$ exhibits a proton conductivity of $4.8 \mathrm{mS} \mathrm{cm}^{-1}$ under very harsh operative conditions (i.e., @ $90{ }^{\circ} \mathrm{C} / 30 \% \mathrm{RH}$ ), which is very close to the Nafion 212 used here as a reference $\left(7.4 \mathrm{mS} \mathrm{cm}^{-1}\right)$. The data reveal the feasibility of producing cost-effective, high-performance membranes based on sPEEK that can work efficiently above $110{ }^{\circ} \mathrm{C}$ and with low humidification.

Author Contributions: Conceptualization, I.N. and A.E.; methodology, C.S.; investigation, E.L., A.E., and C.S.; resources, I.N.; data curation, C.S. and E.L.; writing-original draft preparation, E.L.; writing-review and editing, I.N.; supervision, I.N.; funding acquisition, I.N. All authors have read and agreed to the published version of the manuscript.

Funding: This research received no external funding.

Conflicts of Interest: The authors declare no conflict of interest. 


\section{References}

1. Zhang, H.; Shen, P.K. Recent development of polymer electrolyte membranes for fuel cells. Chem. Rev. 2012, 112, $2780-2832$. [CrossRef] [PubMed]

2. Chen, Y.; Kang, Y.; Zhao, Y.; Wang, L.; Liu, J.; Li, Y.; Liang, Z.; He, X.; Li, X.; Tavajohi, N.; et al. A review of lithium-ion battery safety concerns: The issues, strategies, and testing standards. J. Energy Chem. 2021, 59, 83-99. [CrossRef]

3. Weber, A.Z.; Mench, M.M.; Meyers, J.P.; Ross, P.N.; Gostick, J.T.; Liu, Q. Redox flow batteries: A review. J. Appl. Electrochem. 2011, 41,1137-1164. [CrossRef]

4. Garland, N.L.; Kopasz, J.P. The United States Department of Energy's high temperature, low relative humidity membrane program. J. Power Sources 2007, 172, 94-99. [CrossRef]

5. Xu, J.; Zhang, C.; Wan, Z.; Chen, X.; Chan, S.H.; Tu, Z. Progress and perspectives of integrated thermal management systems in PEM fuel cell vehicles: A review. Renew. Sustain. Energy Rev. 2022, 155, 111908. [CrossRef]

6. Mauritz, K.A.; Moore, R.B. State of understanding of Nafion. Chem. Rev. 2004, 104, 4535-4585. [CrossRef]

7. Yu, J.; Pan, M.; Yuan, R. Nafion/Silicon oxide composite membrane for high temperature proton exchange membrane fuel cell. $J$. Wuhan Univ. Technol. Mater. Sci. Ed. 2012, 22, 478-481. [CrossRef]

8. Lufrano, E.; Simari, C.; Di Vona, M.L.; Nicotera, I.; Narducci, R. How the morphology of nafion-based membranes affects proton transport. Polymers 2021, 13, 359. [CrossRef] [PubMed]

9. Okonkwo, P.C.; Ben Belgacem, I.; Emori, W.; Uzoma, P.C. Nafion degradation mechanisms in proton exchange membrane fuel cell (PEMFC) system: A review. Int. J. Hydrogen Energy 2021, 46, 27956-27973. [CrossRef]

10. Ji, M.; Wei, Z. A Review of Water Management in Polymer Electrolyte Membrane Fuel Cells. Energies 2009, 2, 1057-1106. [CrossRef]

11. Xiao, P.; Li, J.; Tang, H.; Wang, Z.; Pan, M. Physically stable and high performance Aquivion/ePTFE composite membrane for high temperature fuel cell application. J. Memb. Sci. 2013, 442, 65-71. [CrossRef]

12. Karimi, M.B.; Mohammadi, F.; Hooshyari, K. Recent approaches to improve Nafion performance for fuel cell applications: A review. Int. J. Hydrogen Energy 2019, 44, 28919-28938. [CrossRef]

13. Tellez-Cruz, M.M.; Escorihuela, J.; Solorza-Feria, O.; Compañ, V. Proton exchange membrane fuel cells (Pemfcs): Advances and challenges. Polymers 2021, 13, 64. [CrossRef]

14. Wang, L.; Wang, D.; Zhu, G.; Li, J. Synthesis and properties of highly branched sulfonated poly(arylene ether)s as proton exchange membranes. Eur. Polym. J. 2011, 47, 1985-1993. [CrossRef]

15. Siracusano, S.; Baglio, V.; Lufrano, F.; Staiti, P.; Aricò, A.S. Electrochemical characterization of a PEM water electrolyzer based on a sulfonated polysulfone membrane. J. Memb. Sci. 2013, 448, 209-214. [CrossRef]

16. Simari, C.; Vecchio, C.L.; Enotiadis, A.; Davoli, M.; Baglio, V.; Nicotera, I. Toward optimization of a robust low-cost sulfonatedpolyethersulfone containing layered double hydroxide for PEM fuel cells. J. Appl. Polym. Sci. 2019, 136, 47884. [CrossRef]

17. Shin, D.W.; Lee, S.Y.; Lee, C.H.; Lee, K.-S.; Park, C.H.; Mcgrath, J.E.; Zhang, M.; Moore, R.B.; Lingwood, M.D.; Madsen, L.A.; et al. Sulfonated Poly(arylene sulfide sulfone nitrile) Multiblock Copolymers with Ordered Morphology for Proton Exchange Membranes. Macromolecules 2013, 46, 7797-7804. [CrossRef]

18. Zhong, S.; Cui, X.; Cai, H.; Fu, T.; Zhao, C.; Na, H. Crosslinked sulfonated poly(ether ether ketone) proton exchange membranes for direct methanol fuel cell applications. J. Power Sources 2007, 164, 65-72. [CrossRef]

19. Yang, S.; Ahn, Y.; Kim, D. Poly(arylene ether ketone) proton exchange membranes grafted with long aliphatic pendant sulfonated groups for vanadium redox flow batteries. J. Mater. Chem. A 2017, 5, 2261-2270. [CrossRef]

20. Marani, D.; D’Epifanio, A.; Traversa, E.; Miyayama, M.; Licoccia, S. Titania nanosheets (TNS)/Sulfonated poly ether ether ketone (SPEEK) nanocomposite proton exchange membranes for fuel cells. Chem. Mater. 2010, 22, 1126-1133. [CrossRef]

21. Kesava, M.; Dinakaran, K. SnO2 nanoparticles dispersed carboxylated Poly(arylene ether sulfones) nanocomposites for proton exchange membrane fuel cell (PEMFC) applications. Int. J. Hydrogen Energy 2021, 46, 1121-1132. [CrossRef]

22. Karimi, M.B.; Hooshyari, K.; Salarizadeh, P.; Beydaghi, H.; Ortiz-Martínez, V.M.; Ortiz, A.; Ortiz Uribe, I.; Mohammadi, F. A comprehensive review on the proton conductivity of proton exchange membranes (PEMs) under anhydrous conditions: Proton conductivity upper bound. Int. J. Hydrogen Energy 2021, 46, 34413-34437. [CrossRef]

23. Simari, C.; Enotiadis, A.; Lo Vecchio, C.; Baglio, V.; Coppola, L.; Nicotera, I. Advances in hybrid composite membranes engineering for high-performance direct methanol fuel cells by alignment of 2D nanostructures and a dual-layer approach. J. Membr. Sci. 2020, 599, 117858. [CrossRef]

24. De Bonis, C.; Simari, C.; Kosma, V.; Mecheri, B.; D’Epifanio, A.; Allodi, V.; Mariotto, G.; Brutti, S.; Suarez, S.; Pilar, K.; et al. Enhancement of proton mobility and mitigation of methanol crossover in sPEEK fuel cells by an organically modified titania nanofiller. J. Solid State Electrochem. 2016, 20, 1585-1598. [CrossRef]

25. Silva, V.S.; Ruffmann, B.; Silva, H.; Silva, V.B.; Mendes, A.; Madeira, L.M.; Nunes, S. Zirconium oxide hybrid membranes for direct methanol fuel cells-Evaluation of transport properties. J. Memb. Sci. 2006, 284, 137-144. [CrossRef]

26. Simari, C.; Potsi, G.; Policicchio, A.; Perrotta, I.; Nicotera, I. Clay-Carbon Nanotubes Hybrid Materials for Nanocomposite Membranes: Advantages of Branched Structure for Proton Transport under Low Humidity Conditions in PEMFCs. J. Phys. Chem. C 2016, 120, 2574-2584. [CrossRef]

27. Enotiadis, A.; Boutsika, L.G.; Spyrou, K.; Simari, C.; Nicotera, I. A facile approach to fabricating organosilica layered material with sulfonic groups as an efficient filler for polymer electrolyte nanocomposites. New J. Chem. 2017, 41, 9489-9496. [CrossRef] 
28. Kang, Y.; Obaid, M.; Jang, J.; Ham, M.H.; Kim, I.S. Novel sulfonated graphene oxide incorporated polysulfone nanocomposite membranes for enhanced-performance in ultrafiltration process. Chemosphere 2018, 207, 581-589. [CrossRef]

29. Nicotera, I.; Enotiadis, A.; Angjeli, K.; Coppola, L.; Gournis, D. Evaluation of smectite clays as nanofillers for the synthesis of nanocomposite polymer electrolytes for fuel cell applications. Int. J. Hydrogen Energy 2012, 37, 6236-6245. [CrossRef]

30. Sun, C.; Zhang, H.; Luo, X.; Chen, N. A comparative study of Nafion and sulfonated poly(ether ether ketone) membrane performance for iron-chromium redox flow battery. Ionics 2019, 25, 4219-4229. [CrossRef]

31. Nicotera, I.; Simari, C.; Boutsika, L.G.; Coppola, L.; Spyrou, K.; Enotiadis, A. NMR investigation on nanocomposite membranes based on organosilica layered materials bearing different functional groups for PEMFCs. Int. J. Hydrogen Energy 2017, 42, 27940-27949. [CrossRef]

32. Simari, C.; Enotiadis, A.; Nicotera, I. Transport properties and mechanical features of sulfonated polyether ether ketone/organosilica layered materials nanocomposite membranes for fuel cell applications. Membranes 2020, 10, 87. [CrossRef] [PubMed]

33. Banerjee, S.; Kar, K.K. Impact of degree of sulfonation on microstructure, thermal, thermomechanical and physicochemical properties of sulfonated poly ether ether ketone. Polymer 2017, 109, 176-186. [CrossRef]

34. Lufrano, E.; Simari, C.; Vecchio, C.L.; Aricò, A.S.; Baglio, V.; Nicotera, I. Barrier properties of sulfonated polysulfone/layered double hydroxides nanocomposite membrane for direct methanol fuel cell operating at high methanol concentrations. Int. J. Hydrogen Energy 2020, 45, 20647-20658. [CrossRef]

35. Tanner, J.E. Use of the stimulated echo in nmr diffusion studies. J. Chem. Phys. 1970, 52, 2523-2526. [CrossRef]

36. Simari, C.; Lufrano, E.; Godbert, N.; Gournis, D.; Coppola, L.; Nicotera, I. Titanium dioxide grafted on graphene oxide: Hybrid nanofiller for effective and low-cost proton exchange membranes. Nanomaterials 2020, 10, 1572. [CrossRef]

37. Simari, C.; Lufrano, E.; Brunetti, A.; Barbieri, G.; Nicotera, I. Highly-performing and low-cost nanostructured membranes based on Polysulfone and layered doubled hydroxide for high-temperature proton exchange membrane fuel cells. J. Power Sources 2020, 471, 228440. [CrossRef]

38. Simari, C.; Lufrano, E.; Brunetti, A.; Barbieri, G.; Nicotera, I. Polysulfone and organo-modified graphene oxide for new hybrid proton exchange membranes: A green alternative for high-efficiency PEMFCs. Electrochim. Acta 2021, 380, 138214. [CrossRef]

39. Slichter, C. (Ed.) Principles of Magnetic Resonance, 3rd ed.; Springer Science \& Business Media: New York, NY, USA, 1990.

40. Simari, C.; Lufrano, E.; Corrente, G.A.; Nicotera, I. Anisotropic behavior of mechanically extruded sulfonated polysulfone: Implications for proton exchange membrane fuel cell applications. Solid State Ion. 2021, 362, 115581. [CrossRef] 